\title{
Development and nonlinear mathematical modeling of a hybrid land autonomous vehicle that applies agrochemicals to ornamental plants
}

\section{Desarrollo y modelado matemático no lineal de un vehículo autónomo terrestre híbrido que aplica agroquímicos a plantas ornamentales}

\author{
HERNÁNDEZ, Carlos †**, FARÍAS, Nicandro, GARCÍA, Noel and BENAVIDES, J. Reyes \\ Tecnologico Nacional de Mexico, Instituto Tecnológico de Colima, Departamento de Posgrado.
}

ID $1^{\text {st }}$ Author: Carlos, Hernández

ID $1^{\text {st }}$ Coauthor: Nicandro, Farías

ID $2^{\text {nd }}$ Coauthor: Noel, García

ID $3^{\text {rd }}$ Coauthor: J. Reyes, Benavides

DOI: $10.35429 / J R D .2020 .17 .6 .9 .14$

Received: January 19, 2020; Accepted: June 29, 2020

\begin{abstract}
The development of electronics, information and communication technologies have favored the dissemination of precision agriculture. While in other countries important scientific innovations are carried out and Hybrid Land Autonomous Vehicles (VATH) are used in various agricultural activities, in our country there is very little development in this regard and some of these production activities are still manual. This research presents the development and non-linear mathematical modeling of VATH for the automated application of agrochemicals in ornamental plants, for modeling the dynamics of longitudinal velocity, lateral velocity and angular velocity of turn or yaw that were simulated in SciLab are observed with the ISO 3888 standard. For the construction of this vehicle, we took an ATV and other low-cost electronic components that make it more affordable in the national agricultural industry will be considered as a motor base, compared to that proposed in other similar developments.
\end{abstract}

Autonomous Land Vehicle, Precision Agriculture, Formal Modeling, SciLab

\begin{abstract}
Resumen
El desarrollo de la electrónica, las tecnologías de la información y la comunicación han favorecido la difusión de la agricultura de precisión. Mientras que en otros países se realizan importantes innovaciones científicas y se utilizan Vehículos Autónomos Terrestres Hibrido (VATH) en diversas actividades de agricultura, en nuestro país existe muy poco desarrollo al respecto y algunas de estas actividades de producción todavía son realizadas manualmente. En esta investigación se presenta el desarrollo y modelado matemático no lineal del VATH para la aplicación automatizada de agroquímicos en viveros de plantas ornamentales, para el modelado se observaron la dinámica de la velocidad longitudinal, velocidad lateral y velocidad angular de viraje o yaw que fueron simuladas en SciLab con norma ISO 3888. Para la construcción de este vehículo se tomó como base motriz una ATV (cuatrimoto) y demás componentes electrónicos de bajo costo que lo hace más asequible a la industria agrícola nacional, en comparación con lo propuesto en otros desarrollos similares.
\end{abstract}

Vehículo Autónomo Terrestre, Agricultura de precisión, Modelado Formal, SciLab

Citation: HERNÁNDEZ, Carlos, FARÍAS, Nicandro, GARCÍA, Noel and BENAVIDES, J. Reyes. Development and nonlinear mathematical modeling of a hybrid land autonomous vehicle that applies agrochemicals to ornamental plants. Journal of Research and Development. 2020. 6-17: 9-14.

\footnotetext{
* Correspondence to the Author (Email: g1846007@itcolima.edu.mx).

$\dagger$ Researcher contributing as first author.
} 


\section{Introduction}

Autonomous Hybrid Land Vehicles (VATH) for the application of agrochemicals in nurseries has been increasing in recent years and one of the main problems for small entrepreneurs is the cost of it as mentioned (Navarro Cosme, 2016). The automotive industry is a leading sector in technological advancement, although the application of its advances in the mass production of consumer vehicles is very limited by the economic factor, given that there is strong global competitiveness among large multinationals. . This competitiveness, which is essentially economic, can be broken down into several aspects (economic, reliability and type of engine). On the one hand, there is the final cost of the product itself, but economic aspects must also be valued, such as those derived from its use, the reliability of the common elements and the motor itself, as well as those derived from the increase of value for the expectations offered.

Today's vehicles are equipped with many electronically controlled systems, the integration of which is increasing in complexity with the increasing number of features and technologies available to the customer. One way to solve this integration problem may be the introduction of a hierarchical control structure, where all control commands are calculated in parallel in a central algorithm, and where control must take into account interactions between vehicle subsystems, driver and vehicle (Bianchi, A. Borri, G. Burgio, \& MD Di Benedetto, 2009).

This work shows a model with two degrees of freedom that represents VATH as a single front and one rear rim (Bicycle Model); the model includes the dynamics of the direction; roll and transfer angle are neglected in this model in order to study VATH response to slight changes in direction and constant longitudinal speeds.

The parameters analyzed in the plant (VATH) were carried out using the SciLab software, which is considered as free access software, so the cost of the analysis and the total of the vehicle are decreased, thus affecting the customer's economy.

\section{State of the art}

The vehicle built by (Carreño Aguillón, Vacca Melo, \& Lugo Ariza, 2012) consists of not using a gearbox or clutch and replacing them with an electric power controller, coupling the electric motor to the differential input shaft. This solution is possible thanks to the fact that electric motors, unlike thermal motors, develop a high starting torque and offer, in general, a high speed range, the disadvantage of this work is that the steering is not electronic if not which is mechanical and requires human action.

On the other hand, (Pérez Rastelli, 2012) performed the control of the motors with a Proportional, Integral, Derivative (PID) control that fed to a Pulse Width Modulator or PWM for its control in English of the vehicle, in addition to a path profile calculation module powered by steering wheel position sensors to feed back the controller, presenting the area of opportunity in the Integral Proportional Controller (PI) which has inappropriate behavior and many oscillations in the transient.

While the work of (Tjonnas \& Johansen, 2010), presents a yaw stability algorithm, combining with a low level of control of the longitudinal slip angle of the wheel and an adaptive law that estimates the maximum value of the parameter of the coefficient of friction of each wheel.

If we talk about energy economy we can take into account the work (Peredo Ramírez, 2020) where the cost benefit of feeding solar panels to a home is simulated and the viability of the project as in work (De la Cruz Fernández, 2020) Furthermore, (Ramirez Cid, 2020) demonstrates how it is possible to assemble a turbine at low cost and thus have one more option to supply VATH.

\section{Methodology}

The methodology used for this research is illustrated in (Figure 1) 


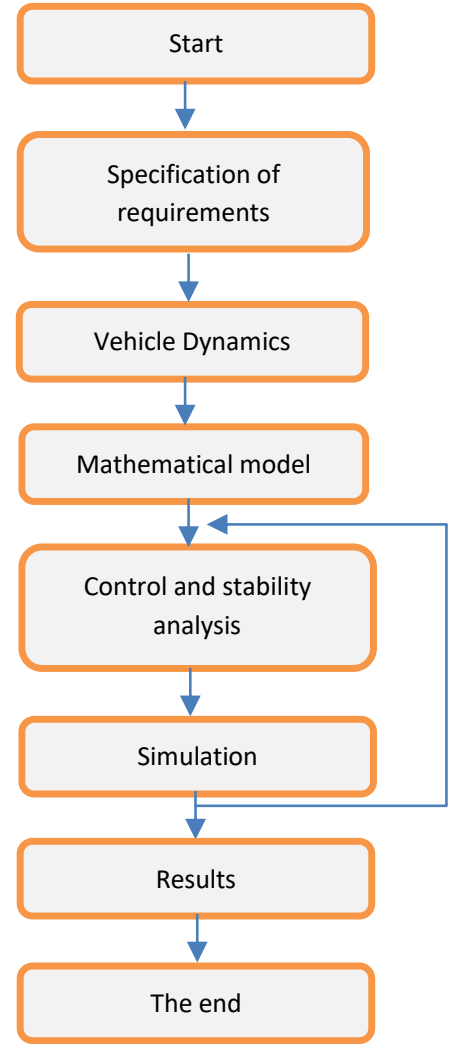

Figure 1 Simulation methodology

\section{VATH Mathematical Model}

The dynamic bicycle model (Figure 2) presented in this section is used in the simulations to estimate car values. In equation (1), the mathematical model of the vehicle used for the simulation is shown, in which three degrees of freedom are considered; longitudinal velocity, lateral velocity, and angular velocity yaw, where they can be expressed using the so-called Bicycle model (Ackermann, Guldner, Steinhausner, \& Utkin, 1995)

$$
\begin{aligned}
& m\left(\dot{v}_{x}-\omega_{z} v_{y}\right)=\mathrm{a}_{\mathrm{x}} \\
& m\left(\dot{v}_{y}-\omega_{z} v_{x}\right)=\mathrm{a}_{\mathrm{y}} \\
& \dot{j}_{z} \dot{\omega}_{z}=\mu\left(\mathrm{F}_{f, y} \mathrm{l}_{f}-\mathrm{F}_{r, y} \mathrm{l}_{r}\right)
\end{aligned}
$$

Where $m, j_{z}$ are the mass and inertia of the vehicle with respect to the perpendicular axis, $l_{f} l_{r}$ are the distances from the vehicle's center of gravity $(\mathrm{CG})$ to the front and rear rim, $a_{x}, \quad a_{y}$ are the longitudinal and lateral acceleration, $\mathrm{v}_{\mathrm{x}}, \mathrm{v}_{\mathrm{y}}$ are the longitudinal and lateral velocities of the CG, $\omega_{-} \mathrm{z}$ is the angular velocity yaw, $\mu$ is the coefficient of friction. Furthermore $\mathrm{F}_{\mathrm{f}, \mathrm{y}}, \mathrm{F}_{\mathrm{r}, \mathrm{y}}$ are the front and rear lateral forces of the tires and it is assumed that there is a high coefficient of friction between the tires and the ground.

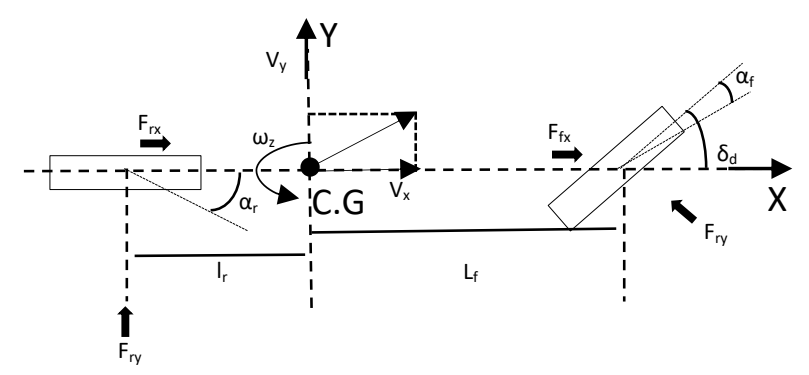

Figure 2 Bicycle Model

Source: (Ackermann, Guldner, Steinhausner, \& Utkin, 1995)

The design specifications are taken from the IFAC reference example (Darenherg, 1993). They are mainly given in terms of maximum guide displacement and maximum steering angle and steering angle speed, all for safety reasons.

For the analysis of forces, the magic formula of (Pacejka, 2005) is used;

$F_{j, i}=D_{j, i} \sin \left(C_{j, i} \arctan _{j, i} \alpha_{j}\right)$

With $i=x, y, j=f, r$. The constants $B_{j, i}, C_{j, i}, D_{j, i}$ in (2) they are experimentally determined (see Table 1). The slip angle of tires $\alpha_{\mathrm{f}}, \alpha_{\mathrm{r}}$ defined as (Di Cairano, Tseng, Bernardini, \& Bemporad, 2013);

$\alpha_{f}=\delta_{d}-\frac{v_{y}+l_{f} w_{z}}{v_{x}}$
$\alpha_{r}=-\frac{v_{y}+l_{r} w_{z}}{v_{x}}$

Where $\delta_{\mathrm{d}}$ is the angle of the wheel:

\begin{tabular}{|l|l|}
\hline $\mathrm{m}=200 \mathrm{~kg}$ & $\mathrm{D}_{\mathrm{r}, \mathrm{y}}=1011 \mathrm{~N}$ \\
\hline $\mathrm{j}_{\mathrm{z}}=460 \mathrm{~kg} \mathrm{~m} \mathrm{~m}^{2}$ & $\mathrm{~B}_{\mathrm{f}, \mathrm{y}}=6.9$ \\
\hline $\mathrm{l}_{\mathrm{r}}=0.32 \mathrm{~m}$ & $\mathrm{C}_{\mathrm{f}, \mathrm{y}}=1.78$ \\
\hline $\mathrm{l}_{\mathrm{f}}=0.68 \mathrm{~m}$ & $\mathrm{D}_{\mathrm{f}, \mathrm{y}}=934 \mathrm{~N}$ \\
\hline $\mathrm{B}_{\mathrm{r}, \mathrm{y}}=10$ & $\mu=0.9$ \\
\hline $\mathrm{C}_{\mathrm{r}, \mathrm{y}}=1.32$ & \\
\hline
\end{tabular}

Table 1 Relative parameters used in the simulation

\section{Results}

In this section the simulation response shown by SciLab is shown, under an ISO 3888-1 maneuver, known as a double steering wheel maneuver or as shown in (figure 3). 


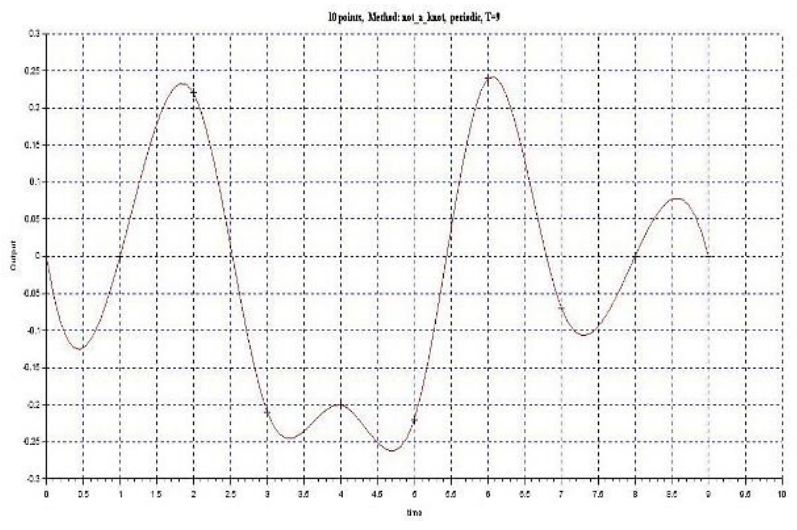

Figure 3 Movement angle in $\mathrm{rad} / \mathrm{s}$

Source: (Sandoval, Ruiz, Topete, \& Gonzalez, 2016)

Next, work with programming in SciLab, with the Xcos Tool taking into account the values of (Table 1) and the following results are obtained (Figure 4, 5, 6):

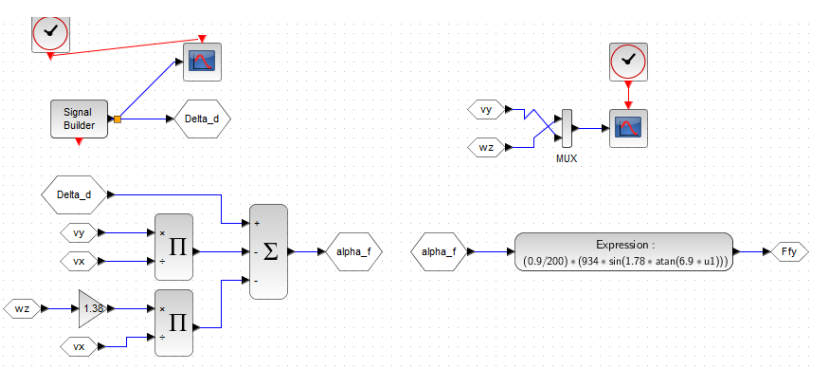

Figure 4 Design in VATH SciLab where Ffy is obtained and the oscilloscopes are shown

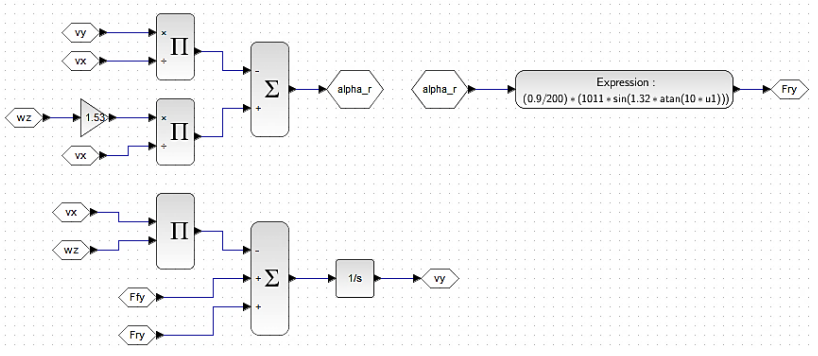

Figure 5 SciLab design of VATH where you get $F_{r y}$

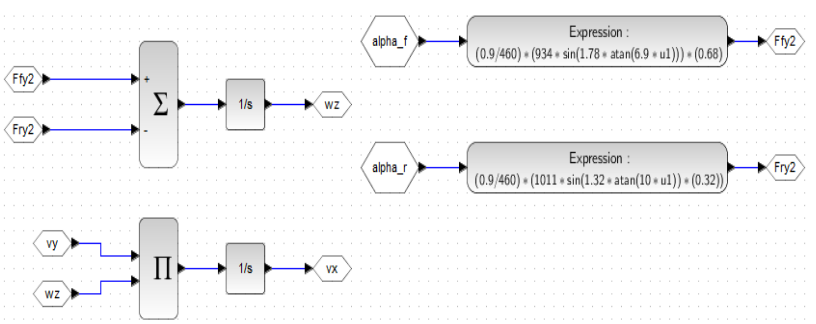

Figure 6 SciLab design of VATH where you get $\mathrm{F}_{\text {fy } 2}$ and $\mathrm{F}_{\mathrm{ry} 2}$

With the VATH mathematical model already simulated in the program with controlled angular velocity yaw (wz) and lateral velocity (Vy) with respect to a Reference System, it is observed in (figure 7).

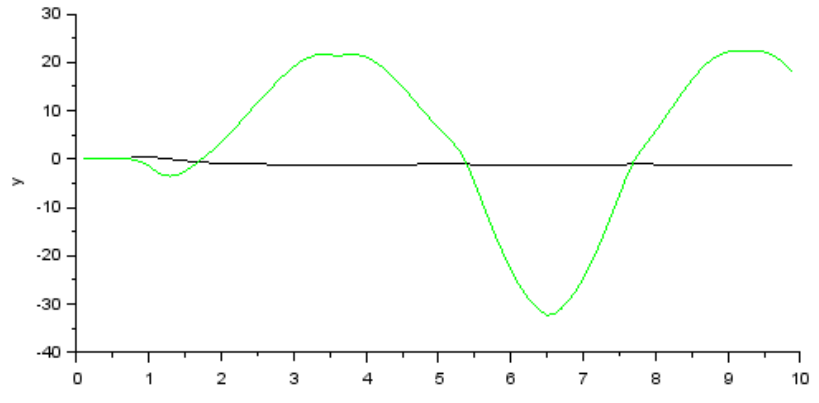

Figure 7 System response to ISO 3888-1 standard where the black line represents $\mathrm{Wz}$ and the green one $\mathrm{V}_{\mathrm{y}}$

Following the research methodology, the response of the System to a unit Step input is tested (figure 8) and the control results are obtained (figure 9):

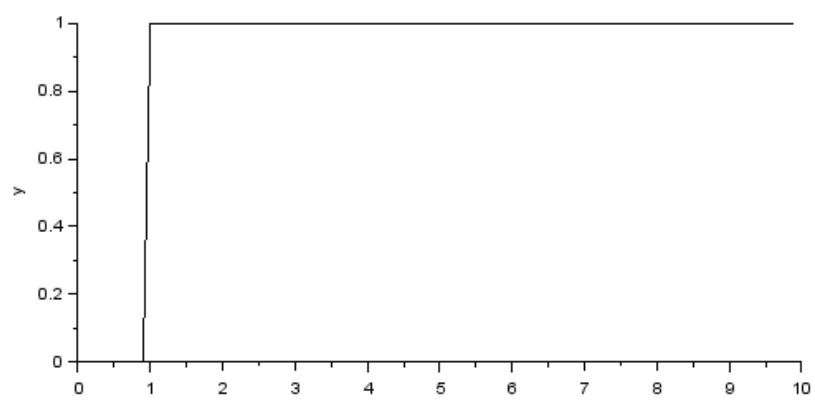

Figure 8 System Entrance to Unit Step

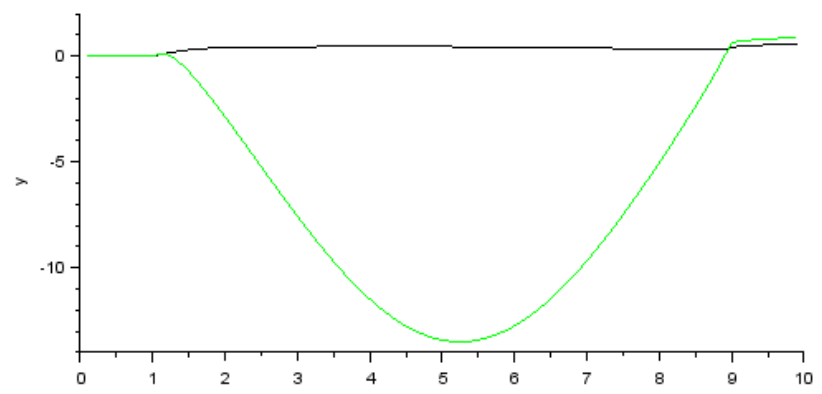

Figure 9 System Response to Unit Step where the black line represents $\mathrm{Wz}$ and the green one $\mathrm{V}_{\mathrm{y}}$

The system response only shows $\mathrm{Vy}$ in the negative order due to the nature of the motion that stabilizes at one value and there is no return to origin, so the lateral velocity decreases when the position is stabilized.

Finally, the system is tested in response to a rectangular unit pulse (figure 10) and obtaining the control results (figure 11): 


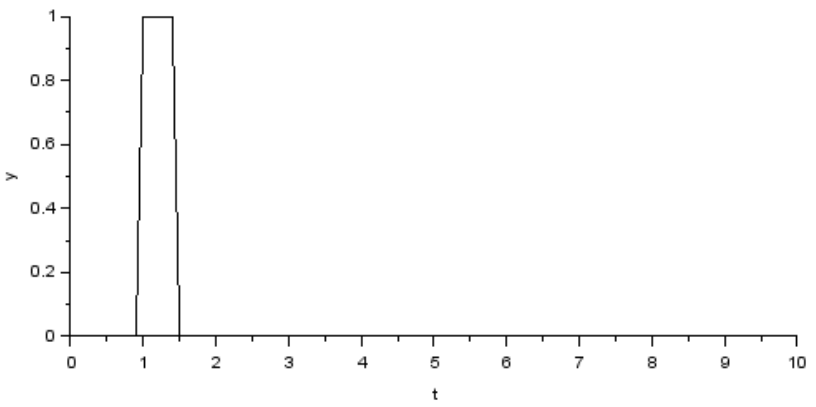

Figure 10 Rectangular unit pulse system input

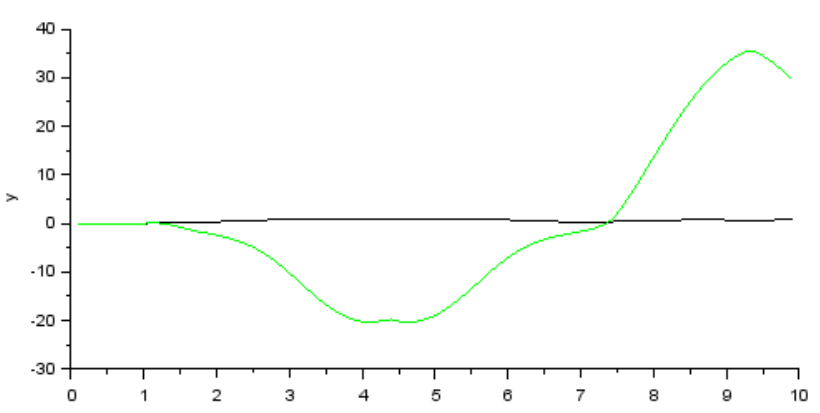

Figure 11 System response to a rectangular unit pulse where the black line represents $\mathrm{Wz}$ and the green $\mathrm{V}_{\mathrm{y}}$

In this case, we can see that the position returns to the origin, so the lateral speed of the return is shown in both positive and negative orders.

\section{Mechanical and structural design}

The overall appearance of the agricultural VATH was based on the Chassis of a mini ATV, a proven motorized transport that due to its already established geometry allows an efficient advance of the Project (figure 12).

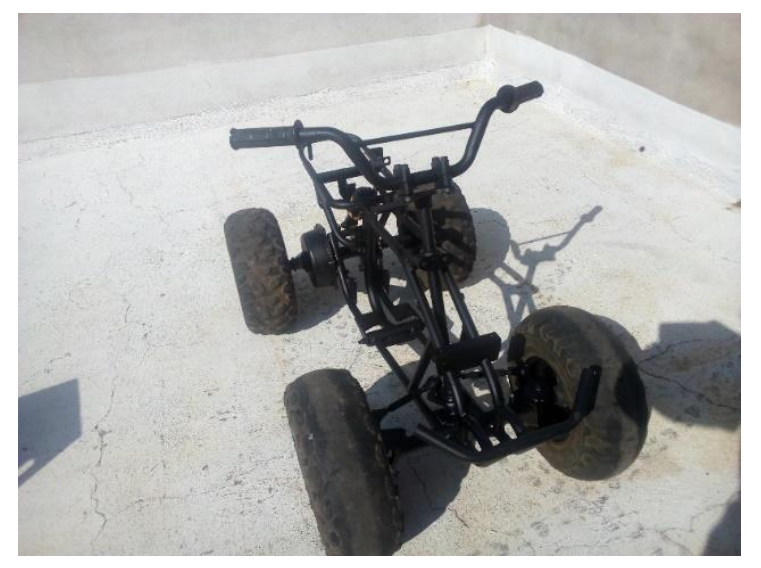

Figure 12 Chassis design for agricultural VATH.

Once the simulation was carried out, the engine was coupled to the vehicle's chassis, the embedded module was mounted and it was taken to the field for testing (Figure 13).

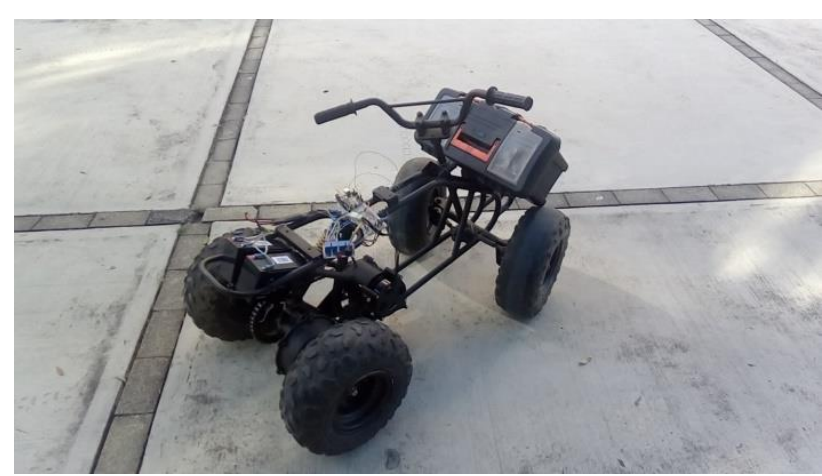

Figuran 13 Chassis under test

\section{Annexes}

\section{Table of symbols}

\begin{tabular}{|c|c|c|}
\hline $\mathrm{m}$ & Vehicle mass & $(\mathrm{kg})$ \\
\hline $\mathrm{j}_{\mathrm{z}}$ & Vehicle moment of inertia & $\left(\mathrm{kg} \mathrm{m}^{\wedge} 2\right)$ \\
\hline $1_{\mathrm{f}}, 1_{\mathrm{r}}$ & $\begin{array}{l}\text { Length from center of } \\
\text { vehicle to front and rear } \\
\text { tire }\end{array}$ & (m) \\
\hline $\mathrm{v}_{\mathrm{x}}$ & Longitudinal speed & $(\mathrm{m} / \mathrm{s})$ \\
\hline$v_{y}$ & Lateral velocity & $(\mathrm{m} / \mathrm{s})$ \\
\hline$\omega_{\mathrm{z}}$ & $\begin{array}{l}\text { Vehicle yaw angular } \\
\text { velocity }\end{array}$ & $(\mathrm{rad} / \mathrm{s})$ \\
\hline$\alpha_{\mathrm{f}}, \alpha_{\mathrm{r}}$ & $\begin{array}{l}\text { Side slip angle of front and } \\
\text { rear tires }\end{array}$ & $(\mathrm{rad} / \mathrm{s})$ \\
\hline$\delta_{\mathrm{d}}$ & $\begin{array}{l}\text { Component of the rim } \\
\text { angle imposed by the } \\
\text { driver }\end{array}$ & $(\mathrm{rad})$ \\
\hline$\omega_{\mathrm{z}}$ & $\begin{array}{lll}\begin{array}{l}\text { Vehicle } \\
\text { velocity }\end{array} & \text { yaw angular } \\
\end{array}$ & $(\mathrm{rad} / \mathrm{s})$ \\
\hline $\mathrm{F}_{\mathrm{f}, \mathrm{y}}, \mathrm{F}_{\mathrm{r}, \mathrm{y}}$ & $\begin{array}{l}\text { Front and rear lateral } \\
\text { forces of the tires }\end{array}$ & $(\mathrm{N})$ \\
\hline $\mathrm{F}_{\mathrm{f}, \mathrm{x}}, \mathrm{F}_{\mathrm{r}, \mathrm{x}}$ & $\begin{array}{l}\text { Front and rear longitudinal } \\
\text { forces of the tires }\end{array}$ & $(\mathrm{N})$ \\
\hline $\mathrm{a}_{\mathrm{x}}, \mathrm{a}_{\mathrm{y}}$ & $\begin{array}{l}\text { Longitudinal and lateral } \\
\text { acceleration }\end{array}$ & $\left(\mathrm{m} / \mathrm{s}^{\wedge} 2\right)$ \\
\hline
\end{tabular}

Table 2

\section{Conclusions}

This research work proposes a linear threedegree-of-freedom model for VATH that applies agrochemicals using the SciLab tool to obtain the System's response, thereby predicting possible maneuvers of the vehicle operating in the field and at the same time reducing the expense necessary for the simulation of the possible environments to which the vehicle will be exposed.

One of the biggest advantages of this VATH design is that the steering is autonomous and therefore avoids the problems of wrong turning caused by the driver. 
In this work, the areas of opportunity detected in the state of the art section were addressed, obtaining results that improve the research presented.

As can be seen in the images of the results, the response of the System is acceptable because it responds very quickly and the type of response is similar to the results obtained with the Carsim program (Sandoval Pérez, Herrera Segura, García, \& Beejinez Macias, 2018 ) (Sandoval, Ruiz, Topete, \& Gonzalez, 2016) (Matamoros Canseco, 2015), additionally the use of SciLab as a free access tool greatly economizes the design of the vehicle.

As future work, the results obtained by the simulation must be compared with field and real-time meters to be able to take specific control actions.

\section{References}

Ackermann, J., Guldner, J., Steinhausner, R., \& Utkin, V. (1995). Linear and nonlinear design for robust automatic steering. IEEE Transactions on Control System Technology, 3(1), 132-143.

Bianchi, D., A. Borri, G. Burgio, \& M. D. Di Benedetto. (2009). Adaptive Integrated Vehicle Control using Active Front Steering and Rear Torque Vectoring. Joint 48th IEEE Conference on Decision and Control and 28th Chinese Control Conference, (p. 1). Shanghai, P.R. China.

Carreño Aguillón, E. d., Vacca Melo, E. A., \& Lugo Ariza, I. (2012). Design and making of an autonomous, solar-energy-powered. Tecnura, 16(32), 91-106.

Darenherg, J. A. (1993, Marzo 19). Automatic track control of a city bus. IFAC Theory Report on Benchmark Problems for Control Systems Design. European control conference.

De la Cruz Fernández, E. (2020). Diseño de un sistema eléctrico aislado utilizando el software HOMER para electrificar el caserío Santa Rosa de Tumar en el distrito de Huambos.
Di Cairano, S., Tseng, H., Bernardini , E., \& Bemporad, A. (2013). Vehicle Yaw Stability Control by Coordinated Active Front Steering and Differential Braking in the Tire Sideslip Angles Domain. IEEE Transactions on Control Systems Technology,, 21(4), 1236-1248.

Matamoros Canseco, D. (2015). SIMULACIÓN DEL COMPORTAMIENTO DINÁMICO DE UN VEHÍCULO EN CARSIM. PROYECTO FIN DE GRADO. MADRID, madrid, España.

Navarro Cosme, T. (2016). Desarrollo de un prototipo de vehículo autónomo. Valencia, España: etsinf.

Pacejka, H. (2005). Tire and Vehicle dynamics. Elsevier.

Peredo Ramírez, E. F. (2020). Diseño de un sistema de generación hibrido eólico solar para la electrificación rural al caserío Inneche del Distrito de Morrope Provincia y Departamento de Lambayeque. Diseño de un sistema Hibrido eólico solar para suministro de energía eléctrica a zona rural en el estado de Chihuahua. Culcyt.

Pérez Rastelli, J. M. (2012). Agentes de control de vehículos. Universidad computense de Madrid, Posgrado, Madrid.

Ramirez Cid, A. \&. (2020). Diseño y simulación de un generador eléctrico por.

Sandoval Pérez, S., Herrera Segura, E., García, J., \& Beejinez Macias, J. (2018). Modelado y simulación de un vehículo en el software carsim. Theorema, 44-49.

Sandoval, S., Ruiz, D., Topete, J., \& Gonzalez, J. (2016). Observador lineal de dos grados de libertad en Matlab-Simulink-CarSim para. Revista Tecnología e Innovación, 1-10.

Tjonnas, J., \& Johansen, T. A. (2010). Stabilization of Automotive Vehicles Using Active Steering and Adaptive Brake Control Allocation. 18(3), 545-558. 